\title{
Effects of Daily Alcohol Intake on Serum and Salivary Alpha-Amylase Activity Associated With Two Local Alcoholic Drinks of Benin
}

\author{
Moutawakilou Gomina (Corresponding author) \\ Laboratory of Biology and Molecular Typing in Microbiology, Department of \\ Biochemistry and Cellular Biology, Faculty of Sciences and Techniques, University of \\ Abomey-Calavi, 05 BP 1604 Cotonou (Republic of Benin). \\ Unit of Studies and Research in Biochemistry, Faculty of Medicine, University of \\ Parakou, BP: 123 Parakou (Republic of Benin). \\ E-mail: elboutraguero@yahoo.fr
}

\begin{abstract}
Haziz Sina
Laboratory of Biology and Molecular Typing in Microbiology, Department of Biochemistry and Cellular Biology, Faculty of Sciences and Techniques, University of Abomey-Calavi, 05 BP 1604 Cotonou (Republic of Benin).
\end{abstract}

Chistianne Gandekon

Unit of Studies and Research in Biochemistry, Faculty of Medicine, University of Parakou, BP: 123 Parakou (Republic of Benin).

E-mail: christiane.rod@gmail.com

\section{Simon Akpona}

Unit of Studies and Research in Biochemistry, Faculty of Medicine, University of Parakou, BP: 123 Parakou (Republic of Benin).

\section{Lamine Baba-Moussa}

Laboratory of Biology and Molecular Typing in Microbiology, Department of Biochemistry and Cellular Biology, Faculty of Sciences and Techniques, University of Abomey-Calavi, 05 BP 1604 Cotonou (Republic of Benin) 
Received: May 28, 2017 Accepted: June 26, 2017 Published: July 19, 2017

doi:10.5296/jbls.v8i2.11298

URL: https://doi.org/10.5296/jbls.v8i2.11298

\begin{abstract}
This study was initiated to assess the effect of daily amount of alcohol intake on serum and salivary alpha-amylase activity of regular adult consumers of tchoukoutou and sodabi, two local alcoholic drinks made in Benin. It was a descriptive, cross-sectional and analytical study carried out from $1^{\text {st }}$ of April to $31^{\text {st }}$ of August, 2012. The study population consisted of 50 subjects as regular consumers of tchoukoutou (titrated with 3\% of alcohol), 50 regular consumers of sodabi (titrated with $40 \%$ of alcohol) and 50 non-consumers of alcohol. Alpha-amylase activity in saliva and serum were measured in each subject. There was no significant difference in the activity of serum and salivary alpha-amylase between consumers of low quantity of tchoukoutou and sodabi $(<30 \mathrm{~g} /$ day) on one hand $(\mathrm{P}=0.24$ and 0.99 respectively), and between moderate consumers (30-79 $\mathrm{g} /$ day) on the other $(\mathrm{P}=0.31$ and 0.48 respectively). Daily amount of alcohol intake had a positive effect on the serum alpha-amylase activity when taking into consideration the entire group at the threshold of $1 \%$, in tchoukoutou consumers $(\mathrm{r}=+0.887)$, and in women sodabi consumers at the threshold of $5 \%(\mathrm{r}=+0.928)$. Therefore, serum alpha-amylase activity is positively associated with the consumption of these two local alcoholic drinks made in Benin.
\end{abstract}

Keywords: Serum, Salivary, Alpha-amylase activity, local alcohol drink, Benin

\title{
1. Introduction
}

Alcohol consumption is one of the leading risk factors for death and disability; it accounts for almost 3 million annual deaths globally and 3.9\% of years of life lost to disease (GBD 2013 Risk Factors Collaborators, 2015). The adverse effects of alcohol use are well characterized such as liver cirrhosis, injuries and several types of cancer (WHO, 2014; GBD 2013 Risk Factors Collaborators, 2015).

Alpha-Amylases (EC 3.2.1.1) retains glycosidases which activity is known to catalyze hydrolysis of internal $\alpha$-1,4-glycosidic bonds in starch (Mosi et al., 1997; Uitdehaag et al., 1999). Whereas salivary amylase is produced by salivary glands and is released predominantly upon adrenergic innervation, amylase in blood is mostly produced and released by pancreas. Pancreatic amylase enters the blood stream and can easily measured in blood (Pieper-Bigelow et al., 1990). Amylase concentrations are highest in the pancreas and salivary glands, although amylase is abundant in other organs as well. Salivary and pancreatic forms of alpha-amylase have gained interest in a variety of areas (Zakowski et Bruns, 1985). The use of saliva as of substance abuse/dependence and monitoring of substance levels, including alcohol and tobacco, has gained high attention in the recent years (Soo-Quee Koh and Choon-Huat Koh, 2007).

Alcoholic beverages contain numerous non-alcoholic constituents that may have beneficial or pathological effects (Gerloff et al., 2010). The two local alcoholic drinks i.e. tchoukoutou 
(titrated with $3 \%$ of alcohol) and sodabi (titrated with $40 \%$ of alcohol), contained non-alcoholic constituents (Gomina et al., 2014). Tchoukoutou and sodabi are largely consumed by the low income population, and significantly contribute to the diets of millions of Beninese and generates income for producers using the traditional technology and retailers. In our previous study, we made the following conclusion: consumption of tchoukoutou and sodabi increases alpha-amylase activity in serum and saliva (Gomina et al., 2013). Through this conclusion, we sought to point out the effect of daily amount of alcohol intake on serum and salivary alpha-amylase activity among regular adult consumers of tchoukoutou and sodabi as two local alcoholic drinks made in Benin.

\section{Materials and Methods}

This research protocol had been registered under No. 172/2012 at the Faculty of Medicine of the University of Parakou (Republic of Benin).

\subsection{Type of Study and Respondents}

It was a cross-sectional and descriptive study with analytical purpose carried out from $1^{\text {st }}$ of April to $31^{\text {st }}$ of August, 2012 in the town of Parakou where the subjects were selected. Samples were handled in the laboratory of the Regional Teaching Hospital of Parakou (Republic of Benin). The study target population consisted of adult subjects (aged 18 years old and more) from both sexes, selected among the population of Parakou after their informed consent. The selected subjects are consumers of one of the two local alcoholic drinks i.e. tchoukoutou (titrated with $3 \%$ of alcohol) and sodabi (titrated with $40 \%$ of alcohol) and non-alcohol consumers. Tobacco smokers and others local or industrial alcoholic drink consumers were excluded. Subjects with overweight or with history of diabetes mellitus, liver disease, high blood pressure, gout, dyslipidemia or with any drug therapy, as well as pregnant women and subjects who did not give their consent were also excluded. The contents of those local alcoholic drinks were previously described (Gomina et al., 2014). A regular consumer was supposed to be any subject consuming at least one standard glass of one of those local alcoholic drinks at a minimal frequency of three times a week, no matter the amount consumed. The subjects were selected as previously described (Gomina et al., 2013). The census of regular consumers of local alcoholic drinks was carried out in the well-known markets and sale points of Parakou during the survey period. In total, 150 subjects were selected: 50 consumers of sodabi (mean age: $37.60 \pm 9.70$ years; 44 men; 06 women), 50 consumers of tchoukoutou (mean age: $36.64 \pm 8.02$ years; 40 men; 10 women) and 50 non-alcohol consumers (mean age: $30.20 \pm 8.64$ years; 34 men; 16 women).

\subsection{Alcohol Intake}

Alcohol intake was measured using a self-assessment questionnaire. Consumption of alcoholic drink was quantified with the criterion of number of standard glass, based on subjects' statements. One standard glass means 10 grams of pure alcohol (ethanol) (François, 2002). The number of standard glass of alcohol intake by one subject was computed by dividing the volume of drink consumed by the volume of standard glass. As regards sodabi, intake volume was computed based on volume of talokpemi. Talokpemi glass has a capacity 
of 40 to $45 \mathrm{~mL}$. We took into account an average of $42.5 \mathrm{~mL}$. The volume of sodabi standard glass is $25 \mathrm{~mL}$ (WHO, 2008). One (1) talokpemi of sodabi is equivalent to 1.7 standard glasses $(42.5 \mathrm{~mL} / 25 \mathrm{~mL})$. The number of standard glass consumed was calculated by multiplying the number of talokpemi consumed by 1.7. As far as tchoukoutou is concerned, consumption volume was calculated with a graduated cylinder to measure the content of one calabash of fifty (50) Francs CFA and by multiplying that amount by the number of calabashes consumed. The content of one calabash of fifty (50) Francs CFA of tchoukoutou is on average $75 \mathrm{~mL}$. As the volume of standard glass of tchoukoutou was $250 \mathrm{~mL}$ (WHO, 2008), the number of standard glass is computed by dividing the consumed volume (in $\mathrm{mL}$ ) by 250. Daily alcohol consumption under $30 \mathrm{~g}$ was considered as low; it was considered as average when between 30 and $79 \mathrm{~g}$ per day; alcohol consumption higher or equal to $80 \mathrm{~g}$ per day was considered high.

\subsection{Data Collection and Processing}

The data were collected using a questionnaire administered to each selected subject. The collected data were age, gender, type of local alcoholic drink consumed, weekly frequency of consumption, and daily amount and duration of alcohol consumption. Venous blood and saliva sample were collected from each subject involved in the study, at morning without doing any exercise, in order to measure serum and salivary alpha-amylase activity. A $4 \mathrm{~mL}$ blood samples were collected through superficial venipuncture in the crook of the elbow on dried tubes, in each study subject after 12 hours fasting period. Saliva samples were collected early in the morning without mouthwash into bottles containing $25 \mathrm{~mL}$. Harvested samples were centrifuged at $4000 \mathrm{rpm}$ during 10 minutes and supernatant were decanted to measure alpha-Amylase concentration that same day. Alpha-amylase activity was determined through kinetic enzymatic method which uses CNP-G3 (2-chloro-4-nitrophenyl-alpha-maltotriosid) (Gella et al., 1997) as substrate. Briefly, on the recommendation of fabricant, $1000 \mu \mathrm{L}$ of reagent was mixed with $25 \mu \mathrm{L}$ of serum or saliva; saliva sample were diluted. The absorbance of the mix was measured on spectrophotometer at $405 \mathrm{~nm}$. Alpha-amylase activity was calculated through the formula below:

Activity $(U I / L)=\Delta A b s \times F ;$ where $\Delta A b s=$ variation of absorbance and $F=2949$.

\subsection{Statistical Analysis}

Data analyses were quantitative. They were performed using SPSS 20 and STATA 13 softwares. The results were expressed as ratios and averages with their standard deviation. As regards comparison of mean values, both Analysis of Variance (ANOVA) of Fisher and Student $t$ test were used. ANOVA test was used to compare the mean values of serum and salivary alpha-amylase activity according to the type of consumers (non-alcohol, tchoukoutou and sodabi consumers). Student's t test was used to compare the mean values of alpha-amylase activity between two types of consumers. Eventually, linear regressions enabled to quantify the effect of alcohol amount on serum and salivary alpha-amylase activity with specification of sex and type of alcohol. We considered 5\% as significance threshold. 


\section{Results}

The average activity of salivary alpha-amylase was significantly different between the three groups of subjects $(\mathrm{p}=0.03)$ (Table 1$)$. The average activity of serum $(\mathrm{p}=0.04)$ and saliva $(\mathrm{p}=0.02)$ alpha-amylase was significantly higher in sodabi consumers compared to non-consumers (Table 1).

Table 1. Comparison of mean values \pm standard deviation of serum and salivary $\alpha$-amylase activity (in UI/L) following the type of alcohol consumption

\begin{tabular}{|c|c|c|c|c|c|c|c|}
\hline & $\begin{array}{l}\text { Non-alcohol } \\
\text { consumers } \\
(n=50)\end{array}$ & $\begin{array}{l}\text { Tchoukoutou } \\
\text { consumers } \\
(\mathrm{n}=50)\end{array}$ & $\begin{array}{c}\text { Sodabi } \\
\text { consumers } \\
(\mathrm{n}=50)\end{array}$ & Pall & Pnt & Pns & Pts \\
\hline $\begin{array}{l}\text { Serum } \\
\alpha \text {-amylase }\end{array}$ & $125.05 \pm 75.74$ & $146.66 \pm 59.10$ & $152.45 \pm 53.92$ & 0.08 & 0.12 & 0.04 & 0.61 \\
\hline $\begin{array}{l}\text { Salivary } \\
\alpha \text {-amylase }\end{array}$ & $\begin{array}{c}85578.34 \\
\pm 61563.39\end{array}$ & $\begin{array}{c}94690.23 \\
\pm 64578.84\end{array}$ & $\begin{array}{c}128042.69 \\
\pm 114725.38\end{array}$ & 0.03 & 0.47 & 0.02 & 0.08 \\
\hline
\end{tabular}

Pall $=$ significance level of the Fisher $\mathrm{F}$ in ANOVA comparison test for 3 types of alcohol consumption; Pnt = significance level of the Student $t$ test between non-alcohol consumers and tchoukoutou consumers; Pns = significance level of the Student $\mathrm{t}$ test between non-alcohol consumers and sodabi consumers; Pts = significance level of the Student $\mathrm{t}$ test between sodabi consumers and tchoukoutou consumers; $\mathrm{n}=$ number.

There was no significant difference in serum and salivary alpha-amylase activity between consumers of low volumes ( $<30 \mathrm{~g} /$ day) of tchoukoutou and sodabi on one hand, and between moderate consumers (30-79 g/ day) of tchoukoutou and sodabi on the other (Table 2).

Table 2. Mean values \pm standard deviation (in UI/L) of serum and salivary $\alpha$-amylase activity according to daily amount of alcohol intake

\begin{tabular}{|l|l|l|l|l|c|}
\hline & $\begin{array}{l}\text { Daily } \\
\text { alcohol } \\
\text { intake }(\mathrm{g})\end{array}$ & $\begin{array}{l}\text { Number of } \\
\text { consumers }\end{array}$ & $\begin{array}{l}\text { Tchoukoutou } \\
\text { consumers }\end{array}$ & Sodabi consumers & \\
\hline \multirow{3}{*}{$\begin{array}{l}\text { Serum } \\
\alpha \text {-amylase }\end{array}$} & $\langle 30$ & 35 & $133.01 \pm 54.66$ & $171.63 \pm 34.75$ & 0.24 \\
\cline { 2 - 6 } & $30-79$ & 45 & $170.93 \pm 60.37$ & $151.17 \pm 64.27$ & 0.31 \\
\cline { 2 - 6 } & $\geq 80$ & 20 & - & $151.30 \pm 40.72$ & NAb \\
\hline \multirow{2}{*}{$\begin{array}{l}\text { Salivary } \\
\alpha \text {-amylase }\end{array}$} & $30-79$ & 45 & $112838.04 \pm 66848.11$ & $135579.10 \pm 124453.75$ & 0.48 \\
\cline { 2 - 6 } & $\geq 80$ & 20 & - & $124489.80 \pm 108255.58$ & NAb \\
\hline
\end{tabular}


$\mathrm{b}$ Those who have high rate of daily alcohol intake were all sodabi consumers, so t of Student and $\mathrm{P}$ were not calculated; $\mathrm{NA}=$ non applicable

In tchoukoutou consumers, the daily amount of alcohol intake had a positive effect on the activity of serum alpha-amylase, considering the whole group at the threshold of $1 \%$ (Table 3). In sodabi consumers, the daily amount of alcohol intake had a positive impact on the activity of serum alpha-amylase in women at the threshold of 5\% (Table 3).

Table 3. Estimated effect of daily alcohol intake's quantity associated with two local alcohol drinks in Benin

\begin{tabular}{|c|c|c|c|c|c|c|}
\hline \multirow[t]{2}{*}{ Models } & \multicolumn{3}{|c|}{$\begin{array}{l}\text { Tchoukoutou }(95 \% \mathrm{CI}) \\
50 \text { consumers and } 50 \text { non consumers }\end{array}$} & \multicolumn{3}{|c|}{$\begin{array}{l}\text { Sodabi }(95 \% \mathrm{CI}) \\
50 \text { consumers and } 50 \text { non consumers }\end{array}$} \\
\hline & Male & Female & All & Male & Female & All \\
\hline $\begin{array}{l}\text { Serum } \\
\alpha \text {-amylas } \\
\text { e (UI/L) }\end{array}$ & $\begin{array}{l}0.735 \\
\left(-0.017 \_1\right. \\
.489)\end{array}$ & $\begin{array}{l}0.714 \\
\left(-0.655 \_2 .\right. \\
083)\end{array}$ & $\begin{array}{l}0.887 * * \\
\left(0.236 \_1.53\right. \\
9)\end{array}$ & $\begin{array}{l}0.035 \\
\left(-0.147 \_0 .\right. \\
217)\end{array}$ & $\begin{array}{l}0.928 * \\
\left(0.148 \_1.7\right. \\
07)\end{array}$ & $\begin{array}{l}0.110 \\
\left(-0.064 \_0 .\right. \\
284)\end{array}$ \\
\hline $\begin{array}{l}\text { Salivary } \\
\alpha \text {-amylas } \\
\text { e (UI/L) }\end{array}$ & $\begin{array}{l}641.618 \\
(-64.338 \\
1347.573)\end{array}$ & $\begin{array}{c}-1285.205 \\
(-2922.032 \\
-351.621)\end{array}$ & $\begin{array}{l}443.145 \\
\left(-219.020 \_1\right. \\
105.309)\end{array}$ & $\begin{array}{l}-52.473 \\
(-268.750 \\
163.804)\end{array}$ & $\begin{array}{l}-133.576 \\
(-923.673 \\
656.522)\end{array}$ & $\begin{array}{l}-26.132 \\
(-230.281 \\
178.016)\end{array}$ \\
\hline \multicolumn{7}{|c|}{$*=\mathrm{P}<5 \% ; * *=\mathrm{P}<1 \%$} \\
\hline
\end{tabular}

\section{Discussion}

The main purpose of this research work was to assess the effect of the daily amount of tchoukoutou and sodabi intake, two local alcoholic drinks made in Benin, on the serum and salivary alpha-amylase activity in young adult subjects.

This study addressed the assumption that chronic alcohol consumption elevates serum alpha-amylase activity. Evidence from in vivo and in vitro studies indicates that ethanol has an influence on acinar cell function in a way that predisposes the cell to autodigestive injury (Apte et al., 2006). Chronic ethanol exposure: (i) increases the content of digestive and 
lysosomal enzymes within acinar cell via an increase in synthesis and a decline in secretion (side-effect of inhibition of exocytosis due to microtubular dysfunction and/or F-actin reorganization within the cell); (ii) decreases the stability of the organelles that contain digestive enzymes and lysosomes (possibly mediated via fatty acid ethyl esters, cholesteryl esters and/or oxidant stress); (iii) potentiates protein plug formation within ductules (which may further block acinar secretion and cause local and upstream effects). Taken together, these effects may facilitate the activation of digestive enzymes by lysosomal enzymes within the acinar cell and, in the presence of an appropriate trigger factor, initiate auto-digestion.

In our research work, salivary alpha-amylase activity of tchoukoutou and sodabi consumers was higher than the one of non-consumers. The increased activity of lysosomal glycosidases in the saliva of alcoholics is attributable to ethanol itself as well as alcohol metabolites, and may occur via many mechanisms: increased lysosomal membrane permeability, delayed removal of the enzymes from saliva, impaired trafficking of lysosomal hydrolases to organelles, enhanced synthesis of enzyme by activated leucocytes or leakage from damaged cells (Waszkiewicz et al., 2013). Therefore, in alcoholics, lysosomal and cellular membranes of the oral cavity tissues (including oral mucosa and salivary glands) may be damaged, and proteases together with glycosidases (including alpha amylase) may be transferred to cytosol, extracellular matrix, and to saliva (Waszkiewicz et al., 2012). To the contrary, some authors have noted a reduction in the activity of salivary alpha-amylase in case of acute administration of alcohol (Enberg et al., 2001; Rohleder and Nater, 2009). In addition, they noted a decline in saliva flow and protein and electrolyte concentration. It is in reality a reduction in saliva secretion which results in a decline in excretion of saliva constituents. Our study focused on chronic consumers of local alcoholic drinks.

Unlike literature data, our study has not noted a significant difference in the activity of serum and saliva alpha-amylase, regardless of daily amount of tchoukoutou and sodabi intake. This observation may suggest the assumption that tchoukoutou and sodabi have the same effect on the activity of serum and saliva alpha-amylase, in spite of their difference in composition. Actually, tchoukoutou contains polyphenols whereas sodabi does not (Gomina et al., 2014). Many herbal plant extracts have been reported for their alpha-amylase inhibitory activity due to the fact that they contain polyphenols. Polyphenols are not only capable of reducing oxidative stress but also of inhibiting carbohydrate hydrolyzing enzymes because of their ability to bind with proteins (Hanamura et al., 2005). The effect of low or moderate consumption of those two alcoholic drinks on the activity of serum and salivary alpha-amylase may be due to alcohol and not to the other non-alcoholic constituents that they contain.

Our study has pointed out that daily amount of alcohol consumed had a positive impact on serum alpha-amylase activity, considering the whole group of tchoukoutou consumers at the threshold of $1 \%$ whereas it had a positive effect on the activity of women's serum alpha-amylase in sodabi consumers at the threshold of 5\%. Research has confirmed the observation that women become more impaired than men after drinking similar quantities of alcohol. In addition, women appear to be more susceptible than men to alcohol's long-term health effects. Significant gender differences in alcohol pharmacokinetics appear to include 
increased bioavailability and faster disappearance rates in women. Women have proportionally more body fat and less water than do men of the same body weights. Some studies allowed that because alcohol is dispersed in body water, women reach higher peak blood alcohol concentration than men after consuming equivalent doses of alcohol, even when doses are adjusted for body weight (Frezza et al., 1990; Taylor et al., 1996). Alpha-amylasemia has been used widely as a diagnostic marker in various conditions; however, mechanisms driving potential changes as well as differential contribution of various sources of amylase are still not well understood and require further research endeavors (Nater et al., 2015). Acute in vivo infusion of ethanol to rats was said to cause pancreas dose-dependent injury characterized by pancreatic edema, acinar vacuolization and activation of trypsinogen (Werner et al., 2002). Chronic intragastric infusion of ethanol with high dietary fat for 4 weeks was also said to cause pancreatic edema and focal changes, including inflammatory cell infiltration and acinar necrosis (Tsukamoto et al., 1988). On the other hand, a significant increase of digestive enzymes content and lysosomal enzymes within the acinar cell, followed by a significant decline in the stability of the organelles that contain these enzymes (zymogen granules and lysosomes respectively), was reported (Wilson et Pirola, 1997). Basal pancreatic (acinar cell) secretion was recently said to be inhibited in ethanol-fed rats (Deng et al., 2004). A declined acinar secretion may further increase the content of digestive enzymes in cells. This increase in enzyme content together with increased potential for contact between lysosomal enzymes (particularly cathepsin B, known to be capable of activating trypsinogen) and digestive enzymes may result in premature intracellular activation of digestive enzymes and, in the presence of (as yet unknown) a triggering agent, an overt attack of pancreatitis (Figarella et al., 1984; Saluja et al., 1996).

This study has some limitations. The sample's small size and the absence in the sample of subjects consuming more than $79 \mathrm{~g} /$ day of tchoukoutou alcohol, do not allow comparisons with their counterparts drinking sodabi. Therefore, we have no meaningful basis to make a formal conclusion.

\section{Conclusion}

It may be concluded that these results have pointed out that there is no significant difference in alpha-amylase activity between low ( $<30 \mathrm{~g} /$ day) and moderate (30-79 g/ day) consumption of tchoukoutou and sodabi. Daily amount of tchoukoutou intake has a positive effect on serum alpha-amylase activity whereas daily amount of sodabi consumed has a positive effect on serum alpha-amylase activity in women only. Further studies are necessary to outline and explain its mechanisms.

\section{References}

Apte, M. V., Pirola, R. C., \& Wilson, J. S. (2006). Molecular Mechanisms of Alcoholic Pancreatitis. Dig Dis. 23, 232-240. https://doi.org/10.1159/000090170

Deng, X., Wood, P. G., Eagon, P. K., \& Whitcomb, D. C. (2004). Chronic alcohol-induced alterations in the pancreatic secretory control mechanisms. Dig Dis Sci., 49(5), 805-819. https://doi.org/10.1023/B:DDAS.0000030093.25897.61 


\section{Mll Macrothink}

Journal of Biology and Life Science

ISSN 2157-6076

2017, Vol. 8, No. 2

Enberg, N., Alho, H., Loimaranta, V., \& Lenander-Lumikari, M. (2001). Saliva flow rate, amylase activity, and protein and electrolyte concentrations in saliva after acute alcohol consumption. Oral Surg Oral Med Oral Pathol Oral Radiol Endod., 92(3), 292-298.

https://doi.org/10.1067/moe.2001.116814

Figarella, C., Amouric, M., \& Guy-Crotte O. (1984). Premature activation of pancreatic zymogens and its role in the pathogeny of chronic calcifying pancreatitis. Dig Dis Sci., 29, 948. https://doi.org/http://link.springer.com/journal/10620

François, P. (2002). Practical assessment of alcohol consumption. Classifications and definitions of drinking behaviors. Gastroenterol Clin Biol., 26, 141-148.

https://doi.org/http://www.sciencedirect.com/science/journal/03998320

Frezza, M., Di Padova, C., Pozzato, G., Terpin, M., Baraona, E., \& Lieber, C. S. (1990). High blood alcohol levels in women. The role of decreased gastric alcohol dehydrogenase activity and firstpass metabolism. N Engl J Med, 322, 95-99.

https://doi.org/10.1056/NEJM199001113220205

GBD 2013 Risk Factors Collaborators. (2015). Global, regional, and national comparative risk assessment of 79 behavioural, environmental and occupational, and metabolic risks or clusters of risks in 188 countries, 1990-2013: a systematic analysis for the Global Burden of Disease Study 2013. Lancet, 386, 2287-2323.

https://doi.org/http://dx.doi.org/10.1016/S0140-6736(15)00128-2

Gerloff, A., Singer, M. V., \& Feick, P. (2010). Beer and its Non-Alcoholic Compounds: Role in Pancreatic Exocrine Secretion, Alcoholic Pancreatitis and Pancreatic Carcinoma. Int. J. Environ. Res. Public Health, 7, 1093-1104. https://doi.org/10.3390/ijerph7031093

Gella, F. -J., Gubern, G., Vidal, R., Canalias, F. (1997). Determination of total and pancreatic alpha-amylase in human serum with 2-chloro-4-nitrophényl-alpha-D-maltotrioside as substrate. Clin Chim Acta, 259(1-2), 147-160.

https://doi.org/10.1016/s0009-8981(96)06481-9

Gomina, M., Seni, M., \& Akpona, S. A. (2013). Activité de l'alpha amylase sérique et salivaire des sujets adultes consommateurs habituels de deux boissons alcoolisées locales du Bénin. European Scientific Journal, 9(27), 165-176.

Gomina, M., Ahlonsou, G. E. S., Awede, B., Laleye, A., \& Akpona, S. A. (2014). Serum Lipid Profile of the Adult Habitual Consumers of Two Traditional Alcoholic Drinks Made in Benin. IJSBAR, 14(1), 444-554.

Hanamura, T., Hagiwara, T., \& Kawagishi, H. (2005). Structural and functional characterization of polyphenols isolated from acerola (Malpighia emarginata DC.) fruit. Biosci Biotechnol Biochem., 69, 280-286. http://dx.doi.org/10.1080/09168451.2017.1313696

Mosi, R., He, S., Uitdehaag, J., Dijkstra, B .W., \& Withers, S. G. (1997). Trapping and characterization of the reaction intermediate in cyclodextrin glycosyltransferase by use of activated substrates and a mutant enzyme. Biochemistry, 36, 9927-9934. 
https://doi.org/10.1021/acs.biochem.6b01200

Nater, U. M., La Marca, R., Erni, K., \& Ehlert, U. (2015). Alpha-Amylase Activity in Blood Increases after Pharmacological, But Not Psychological, Activation of the Adrenergic System. PLOS ONE, 25. https://doi.org/10.1371/journal.pone.0130449

Pieper-Bigelow, C., Strocchi, A., \& Levitt, M. D. (1990). Where does serum amylase come from and where does it go? Gastroenterol Clin North Am., 19(4), 793-810.

Rohleder, N., \& Nater, U. M. (2009). Determinants of salivary a-amylase in humans and methodological considerations. Psychoneuroendocrinology, 34, 469-485.

http://dx.doi.org/10.1016/j.psyneuen.2017.05.012

Saluja, A., Donovan, E., Yamanaka, K., Yamaguchi, Y., Hofbauer, B., \& Steer, M. (1996). Inhibition of cathepsin $\mathrm{b}$ activity blocks caerulein induced in vitro activation of trypsinogen in rat pancreatic acini. Gastroenterology, 110, A428.

http://dx.doi.org/10.1053/j.gastro.2017.02.040

Soo-Quee Koh, D., \& Choon-Huat Koh, G. (2007). The use of salivary biomarkers in occupational and environmental medicine. Occup Environ Med, 64, 202-220.

http://dx.doi.org/10.1136/oemed-2016-104103

Taylor, J. L., Dolhert, N., Friedman, L., Mumenthaler, M.S., \& Yesavage J. A. (1996). Alcohol elimination and simulator performance of male and female aviators: A preliminary report. Aviation Space and Environmental Medicine, 67(5), 407-413.

Tsukamoto, H., Towner, S. J., Yu, G. S., \& French, S. W. (1988). Potentiation of ethanol-induced pancreatic injury by dietary fat. Induction of chronic pancreatitis by alcohol in rats. Am J Pathol, 131, 246-257. http://dx.doi.org/10.1016/j.ajpath.2017.03.014

Uitdehaag, J. C. M., Mosi, R., Kalk., K. H., van der Veen, B. A., Dijkhuizen, L., Withers, S. G., \& Dijkstra, B. W. (1999). X-ray structures along the reaction pathway of cyclodextrin glycosyltransferase elucidate catalysis in the $\alpha$-amylase family. Nat. Struct. Mol. Biol., 6, 432-436. https://doi.org/10.1038/nsmb.3419

Waszkiewicz, N., Zalewska, A., Szajda, S. D., Szulc, A., Kępka, A., Minarowska, A., Wojewódzka-Żelezniakowicz, M., Konarzewska, B., Chojnowska, S., Supronowicz, Z. B., Ladny, J. R., \& Zwierz, K. (2012). The effect of chronic alcohol intoxication and smoking on the activity of oral peroxidase. Folia Histochem Cytobiol, 50, 450-455.

https://doi.org/10.5603/fhc.2012.0062

Waszkiewicz, N., Chojnowska, S., Zalewska, A., Zwierz, K., Szulc, A., \& Szajda, S. D. (2013). Salivary hexosaminidase in smoking alcoholics with bad periodontal and dental states. Drug Alcohol Depend, 129, 33-40. https://doi.org/10.1016/j.drugalcdep.2012.09.008

Werner, J., Saghir, M., Warshaw, A. L., Lewandrowski, K. B., Laposata, M., Iozzo, R. V., Carter, E. A., Schatz, R. J., \& Fernandez-Del Castillo, C. (2002). Alcoholic pancreatitis in rats: injury from nonoxidative metabolites of ethanol. Am J Physiol Gastrointest Liver Physiol, 283, G65-G73. https://doi.org/10.1152/ajpgi.00419.2001 


\section{Macrothink}

Journal of Biology and Life Science

ISSN 2157-6076 2017, Vol. 8, No. 2

Wilson, J. S, \& Pirola R. C. (1997). The drinker's pancreas: molecular mechanisms emerge. Gastroenterology, 113, 355-358.

World Health Organization (WHO), (2008). “STEP surveillance Manual, Part 1", Geneva, World Health Organization.

World Health Organization. (2014). Global Status Report on Alcohol a Health 2014. Geneva: WHO.

Zakowski J. J., \& Bruns D. E. (1985). Biochemistry of human alpha amylase isoenzymes. Crit Rev Clin Lab Sci., 21(4), 283-322.

\section{Copyright Disclaimer}

Copyright for this article is retained by the author(s), with first publication rights granted to the journal.

This is an open-access article distributed under the terms and conditions of the Creative Commons Attribution license (http://creativecommons.org/licenses/by/3.0/). 